\title{
Proudění v oblouku Podkrušnohorského přivaděče
}

\section{MARTIN KRÁLÍK, TOMÁŠ KAŠPAR, MICHAEL MILDNER}

Klíčová slova: fyzikální modelování - matematické modelování - modelová podobnost - obdélníkové koryto - proudění v oblouku - rychlostní pole

\section{SOUHRN}

Článek se zabývá hydraulickým výzkumem proudění v oblasti oblouku v lokalitě Podkrušnohorského přivaděče (PKP IV - ř. km 2,812-2,736). Koryto privivaděče $\checkmark$ oblouku je lichoběžníkového průřezu se sklonem stěn 9 : 1. Proudění je převážně bystřinného charakteru.

Měření probíhala na fyzikálním modelu v měřítku $1: 15$, který byl postaven členy katedry hydrotechniky ve vodohospodářské laboratoři Fakulty stavební, ČVUT. Na fyzikálním modelu byly měřeny rychlosti a hladiny v celkem devíti profilech. Dále byl sestaven 3D matematický model v programu Ansys CFX, na kterém je možné kromě rychlostí a hladin pozorovat tvar proudového pole. Cílem výzkumu je vyhodnocení proudění v oblasti oblouku v režimu bystřinného proudění pomocí metod hybridního modelování a také verifikace matematického modelu pomocí hodnot naměřených na modelu.

\section{ÚVOD}

Přivaděč je soustava vodních kanálů, podzemních potrubí, nádrží a akvaduktu na Mostecku. Jeho výstavba probíhala v letech 1957-1982. Soustava se skládá z Přivaděče průmyslové vody a z Podkrušnohorského přivaděče. Účelem této 33,8 km dlouhé soustavy kanálu je ochrana před průnikem povrchových vod do hnědouhelných lomů Libouš, Šverma, Obránců míru a ČSA. Další funkcí je přivádět vodu z povodí řeky Ohře pro průmysl na Chomutovsku a Mostecku.

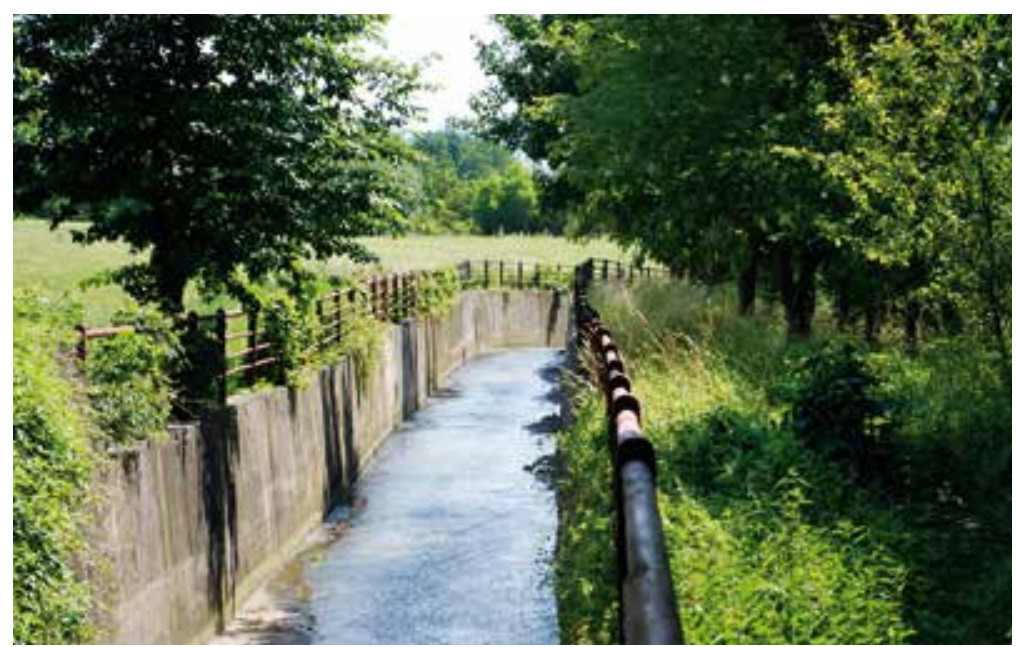

Obr. 1. Podkrušnohorský přivaděč Fig. 1. Podkrušnohorský canal

Zkoumaný oblouk se nachází v úseku PKP IV - ř. km 2,812-2,736, který se nachází u obce Vysoká Pec (obr. 1, 2). Úsek má lichoběžníkový profil se sklony stěn $9: 1$ a šířky ve dně 3,6 m, podélný sklon je 4,7\%, poloměr oblouku je 60 m. Jeho celková délka je necelých 80 m [1].

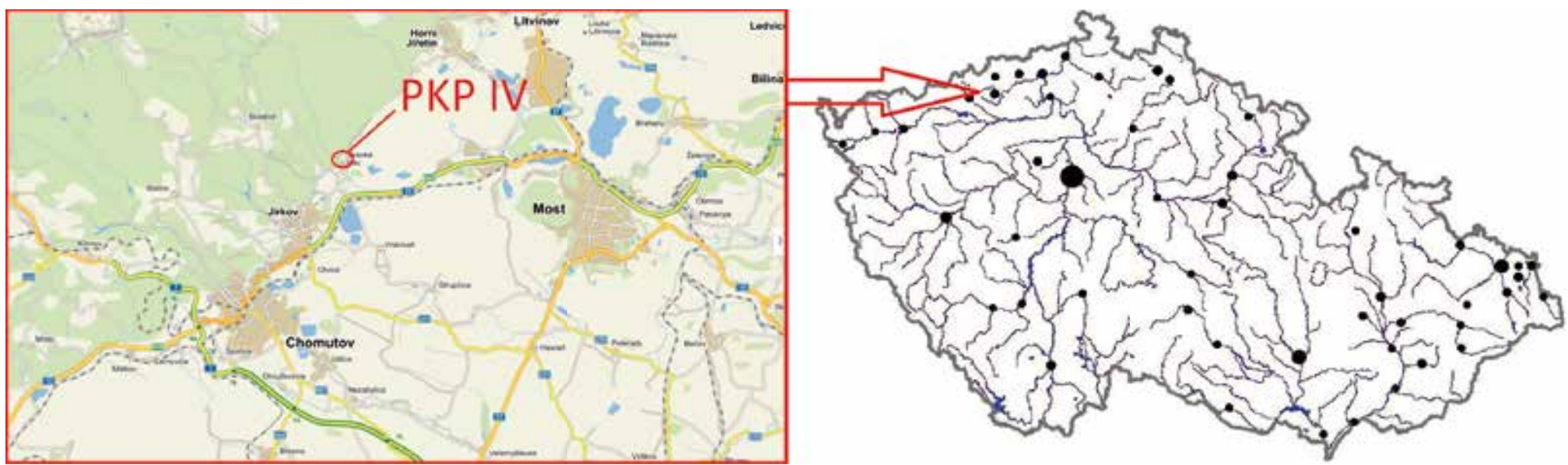

Obr. 2. Mapa PKP

Fig. 2. Map of PKP 
Tabulka 1. Měrené rychlosti - profil 6

Table 1. Measured velocity - profile 6

\section{Rychlosti profil 6}

\begin{tabular}{llllll} 
Úroveň $[\mathrm{m}]$ & $\mathbf{P 1}[\mathrm{m} / \mathrm{s}]$ & $\mathbf{P} \mathbf{2}[\mathrm{m} / \mathrm{s}]$ & $\mathbf{P 3}[\mathrm{m} / \mathrm{s}]$ & $\mathbf{P 4}[\mathrm{m} / \mathrm{s}]$ & $\mathbf{P 5}[\mathrm{m} / \mathrm{s}]$ \\
\hline 0,375 & 6,78 & 7,17 & 7,82 & 7,86 & 6,89 \\
\hline 0,600 & 7,20 & 7,98 & 8,21 & 8,25 & 6,97 \\
\hline 0,750 & 7,24 & 7,98 & 8,06 & 8,17 & 7,09 \\
\hline 0,900 & 7,36 & 7,90 & 7,94 & 8,02 & 7,44 \\
\hline 1,200 & 7,17 & 7,71 & 7,71 & 7,90 & 7,44 \\
\hline 1,350 & 7,09 & 7,55 & 7,67 & 7,86 & 7,63 \\
\hline 1,500 & 6,97 & 7,44 & 7,47 & 7,75 & \\
\hline 1,650 & 6,82 & 7,32 & 7,55 & & \\
\hline
\end{tabular}

\section{FYZIKÁLNÍ MODEL}

\section{Modelové podmínky}

Model byl sestaven členy katedry hydrotechniky ve vodohospodářské laboratoři Fakulty stavební, ČVUT v rámci výzkumného projektu PPV a PKP - doplnění bezpečnostních prvků v korytě toku.

Pro fyzikální model bylo zvoleno měřítko 1: 15 a přístup podle Froudova zákona podobnosti. U tohoto typu modelové podobnosti jsou vyjádřeny podmínky dynamické podobnosti hydrodynamických jevů za výhradního pưsobení gravitačních sil.

Kromě gravitačních sil však mohou zkoumané proudění ovlivňovat i další síly - odpor třením vazké kapaliny, síly kapilární, síly objemové apod. Podle Froudova zákona podobnosti můžeme určitý hydrodynamický jev zkoumat tehdy, jestliže účinky těchto sil jsou zanedbatelné v porovnání s gravitačními silami. Mezní podmínky vymezují oblasti a měřítka, v nichž lze hydrodynamický jev modelovat.

Kinematicky podobné jevy, které ovlivňuje výhradně gravitační síla, jsou dynamicky podobné, jestliže ve vzájemně př́ílušných prưřezech budou stejná Froudova čísla. Fyzikální model v měřítku 1 : 15 odpovídá všem podmínkám [2, 3].

Na základě modelových podobností vyplývají pro použité geometrické měřítko 1 : 15 následující podmínky:

$\begin{array}{lc}\text { Geometrické měř́tko: } & M_{h}=M_{1}=M_{b}=15 \\ \text { Měrítko rychlostí: } & M_{v}=M_{1}^{1 / 2}=3,87 \\ \text { Měrítko průtoků: } & M_{Q}=M_{1}^{5 / 2}=871,42 \\ \text { Měřitko časů: } & M_{t}=M_{1}^{1 / 2}=3,87\end{array}$

\section{Popis modelu}

Model, viz obr. 3, je tvořen uklidňovací a nátokovou nádrží, celkem 21 příčnými profily vymezujícími tvar modelu (10 profilů před objektem (vývarem) tvořící zatáčku, 6 profilů objektových a 5 profilů za objektem). V rámci této práce je pozornost zaměřena pouze na prvních 10 profilů před objektem vývaru.

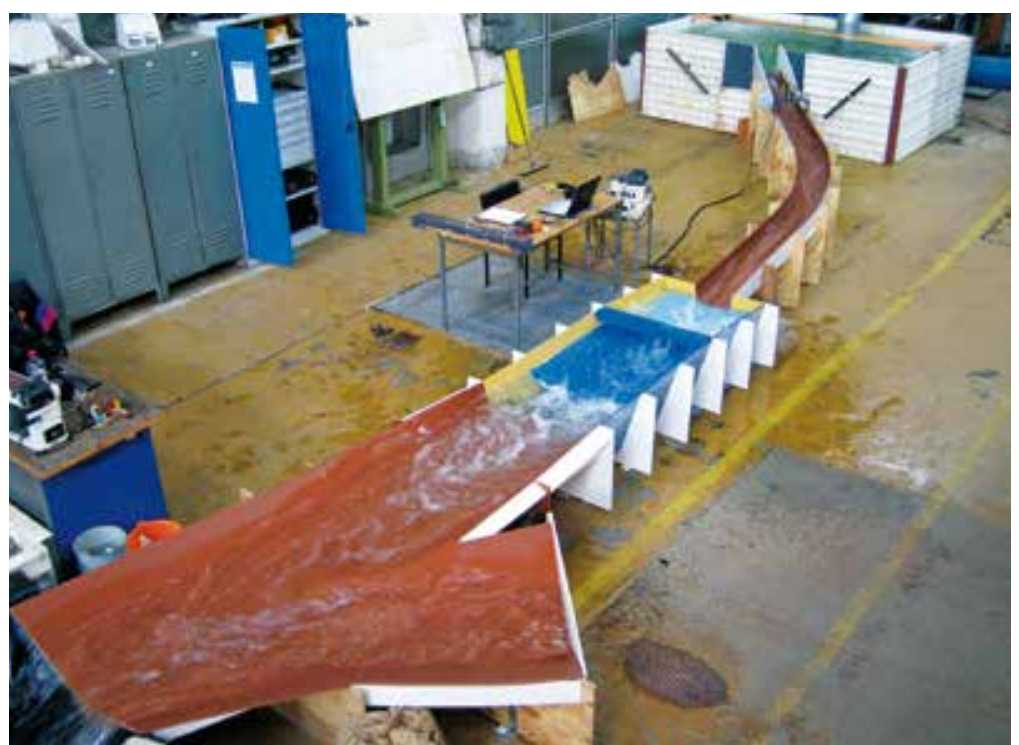

Obr. 3. Fyzikální model PKP Fig. 3. Physical Model of PKP

\section{Měřené veličiny}

Rychlostní pole bylo měřeno pomocí dvou hydrometrických vrtulek typu STS 005 firmy Erfisinger electronic GmbH a dataloggeru. Získaná hodnota rychlosti je průměrná hodnota z 30 sekund měření. Měření probíhalo v každém profilu $\checkmark 5$ bodech $\vee$ jednotlivých hloubkách. Rastr měření je vidět v tabulce 1. Celkem bylo měřeno 8 profilů, a to profil č. 3 až profil č. 10.

Měřené hloubky (obr. 4) byly převzaty z předešlých měření v rámci výzkumného projektu PPV a PKP - doplnění bezpečnostních prvků v korytě toku. Polohy hladin byly měřeny $v$ každém profilu ve čtyřech bodech. Jako měřicí zařízení sloužily ultrazvukové sondy. Frekvence odečtu sond je $10 \mathrm{~Hz}$ a hodnoty hladin jsou následně získány jako prưměr přes 10sekundový interval na každém profilu.

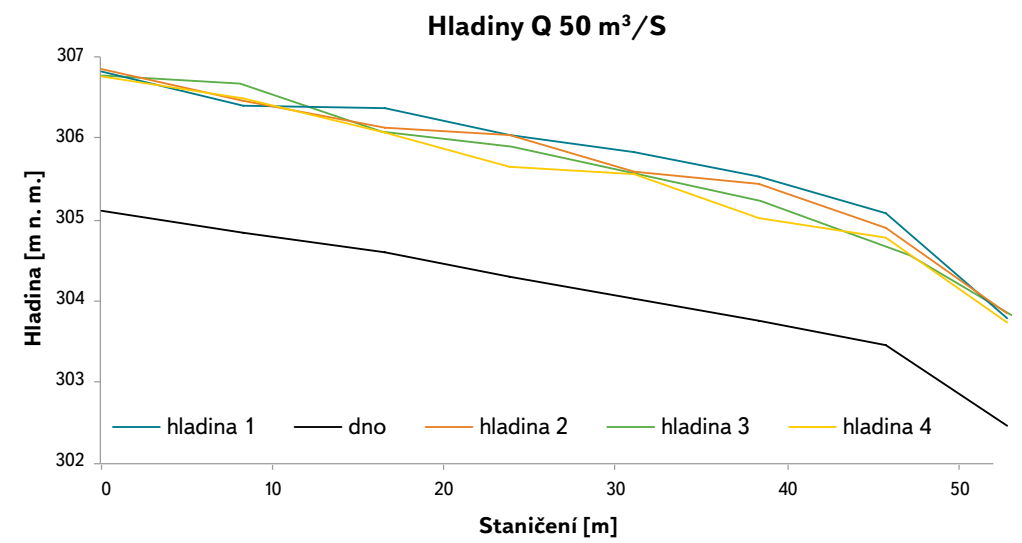

Obr. 4. Podélný profil

Fig. 4. Longitudinal profile

Měěení probíhala $v$ ustáleném režimu, kdy byla horní okrajová podmínka nastavena průtokem. Dolní okrajová podmínka byla tvořena nezatopeným výtokem.

Rychlostní pole na modelu bylo měřeno celkem na šesti průtocích, a to 5, 10, $20,30,40$ a $50 \mathrm{~m}^{3} \cdot \mathrm{s}^{-1}$. 


\section{MATEMATICKÝ MODEL}

V rámci výzkumu byl sestaven matematický model, který se skládá z nátokové nádrže a zkoumané části oblouku ukončené před vývarem (obr. 5).

Výpočetní sít byla vytvořena v programu ICEM CFD, který je součástí platformy ANSYS Workbench. Byla vytvořena strukturovaná sít (mesh) o maximální velikosti elementu $1 \mathrm{~m}$. V místě oblouku byla sít zahuštěna na maximální velikost elementu $30 \mathrm{~cm}$, aby nedocházelo ke zkreslení proudění v oblouku. Celkový počet elementů tak dosáhl 1126315.

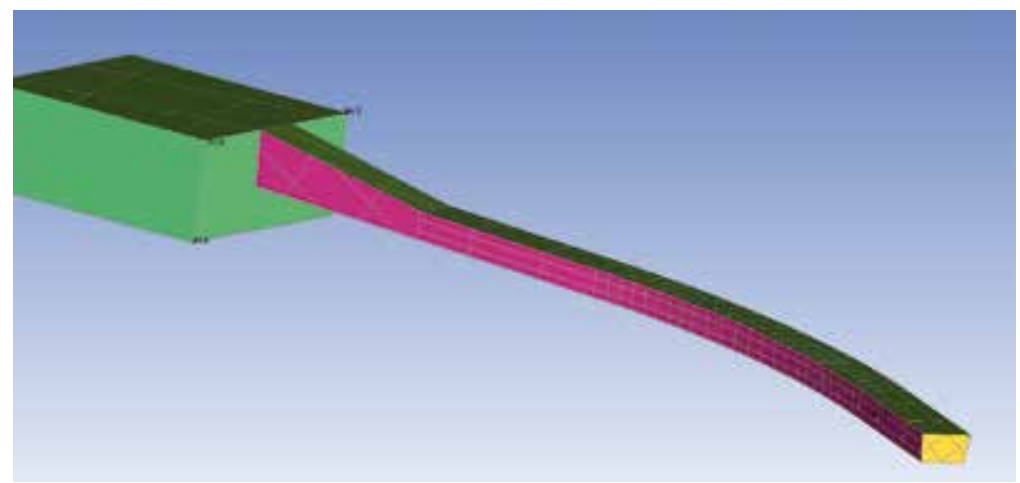

Obr. 5. Geometrie matematického modelu

Fig. 5. Geometry of the numerical model

Pro samotný výpočet byl použit program CFX, který je také součástí platformy ANSYS Workbench. Horní i dolní okrajová podmínka byla nastavena pomocí hladiny, které na fyzikálním modelu odpovídaly průtoku $50 \mathrm{~m}^{3} . \mathrm{s}^{-1}$. Tento průtok pak sloužil pro kalibraci modelu. Kalibrace probíhala pomocí drsnosti stěn, kde počáteční hodnota drsnosti 0,014 byla měněna až na tzv. hladkou stěnu (no slip wall) $[4,5]$.

Model byl nastaven tak, aby umožňoval proudění s volnou hladinou (dvoufázové proudění voda-vzduch). Samotný výpočet je nastavený jako ustálené proudění.
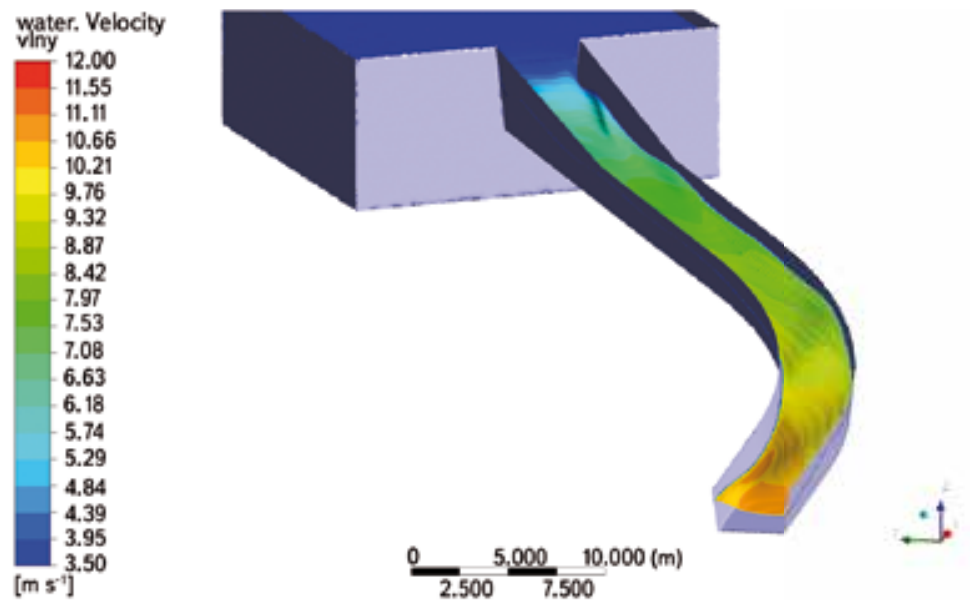

Obr. 6. Tvar hladiny z matematického modelu

Fig. 6. The shape of water level of the numerical model

\section{VYHODNOCENÍ}

Rychlostní pole byla vyhodnocena pro návrhový maximální průtok $50 \mathrm{~m}^{3} \cdot \mathrm{s}^{-1}$. Rychlosti byly vykresleny pomocí plošné interpolace do jednotlivých profilů (obr. 6 a 7). Maximální rychlosti dosahovaly téměř $9 \mathrm{~ms}^{-1}$. Rozložení rychlostí v jednotlivých profilech je plynulé, z toho lze vyvodit, že v celém oblouku nedochází k velkým turbulencím.

\section{PROFIL 3}

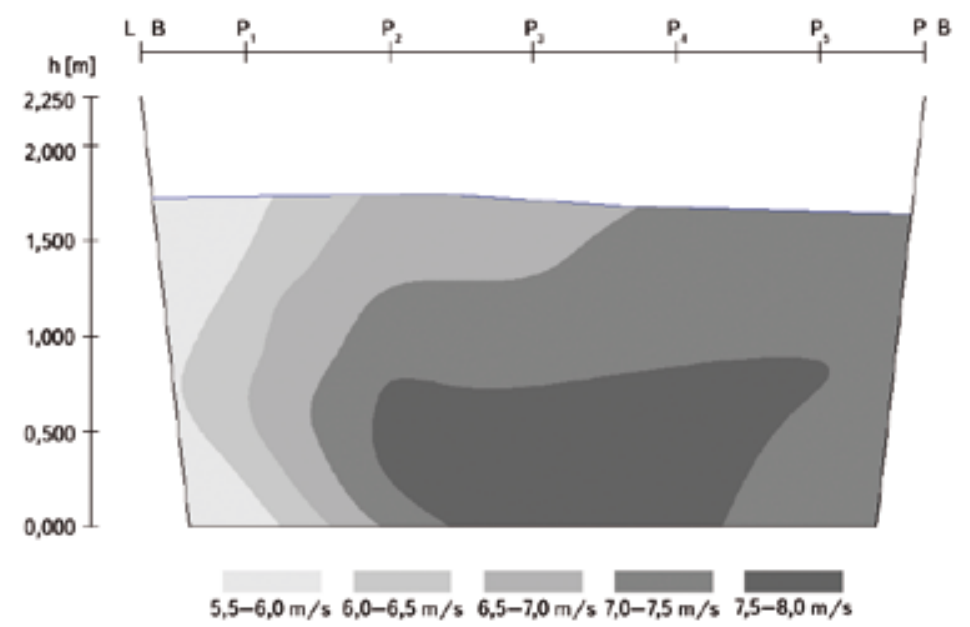

Obr. 7. Rychlosti profil 3

Fig. 7. The velocity profile 3

\section{PROFIL 6}

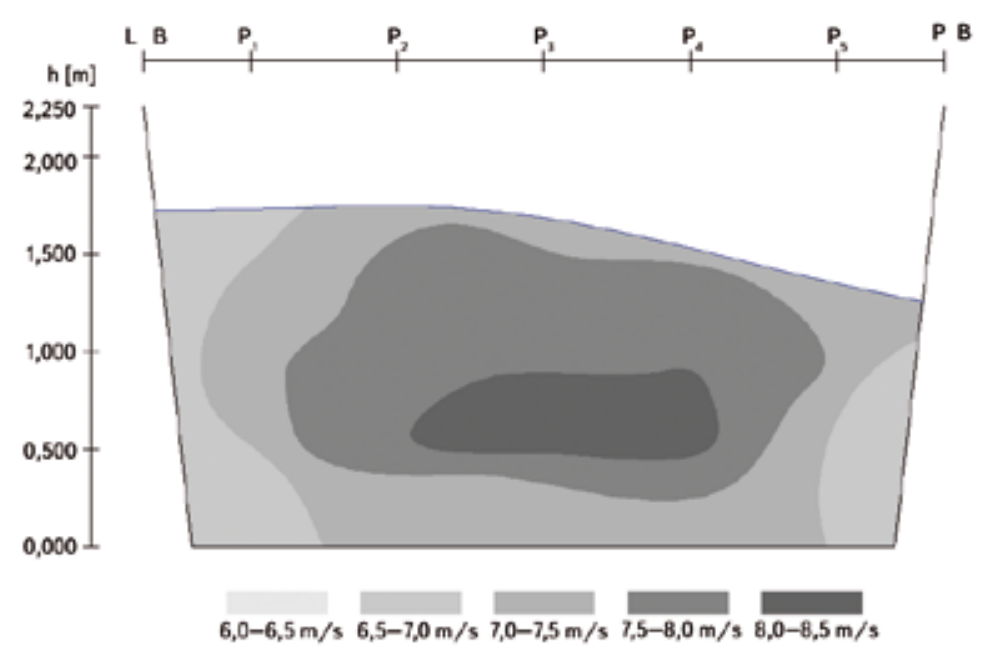

Obr. 8. Rychlosti profil 6

Fig. 8. The velocity profile 6 


\section{PROFIL 9}

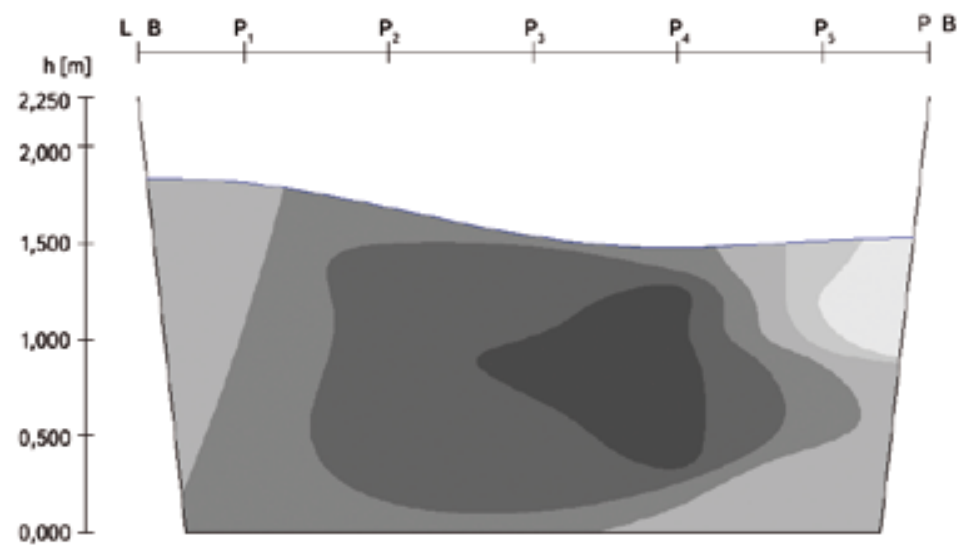

$6,0-6,5 \mathrm{~m} / \mathrm{s} \quad 6,5-7,0 \mathrm{~m} / \mathrm{s} \quad 7,0-7,5 \mathrm{~m} / \mathrm{s} \quad 7,5-8,0 \mathrm{~m} / \mathrm{s} \quad 8,0-8,5 \mathrm{~m} / \mathrm{s} \quad 8,5-9,0 \mathrm{~m} / \mathrm{s}$

Obr. 9. Rychlosti profil 9

Fig. 9. The velocity profile 9

Matematický model umožnil popsat proudová pole. Na základě pozorování hladiny se očekávalo značně turbulentní proudění a šroubovitý tvar proudnic $\checkmark$ druhé polovině oblouku. Oproti tomuto předpokladu se ukázalo, že proudnice jsou téměř plynulé a jsou plynulé v celé délce oblouku, viz obr. 8, 9a 10.

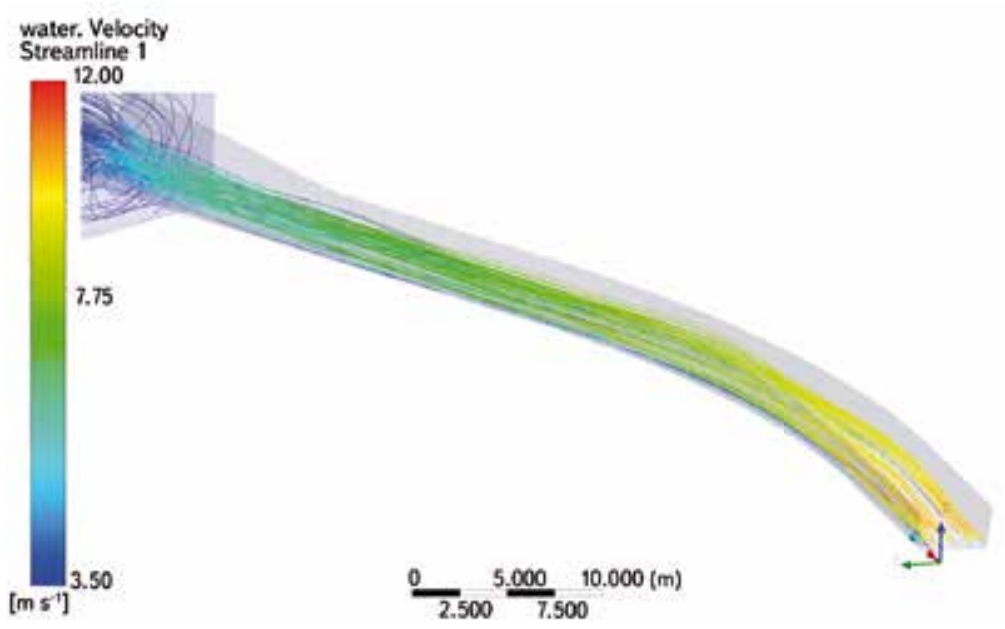

Obr. 10. Proudnice

Fig. 10. Streamline

\section{ZÁVĚR}

V rámci výzkumu bylo zkoumáno proudění v oblouku s velkým sklonem dna a bystřinným charakterem proudění. Metodou hybridního modelování bylo možné vyhodnotit nejen rychlosti v jednotlivých profilech, ale také proudová pole v tomto úseku, které bylo možno určit po úspěšné verifikaci matematického modelu z naměřeného průběhu hladin na fyzikálním modelu. Výzkum ukázal, že při vysokém sklonu dna i při velkých průtocích nedochází k turbulentnímu proudění v obloucích.

\section{Literatura}

[1] SATRAPA, L. aj. PPV a PKP - Doplněníbezpečnostnich prvkư v korytě toku. Praha: ČVUT, 2014.

[2] ČÁBELKA, J. a GABRIEL, P. Matematické a fyzikálnímodelovanív hydrotechnice (1) Výzkum na hydraulických modelech a ve skutečnosti. Praha: Academia, 1987

[3] KOLÁŘ, V., PATOČKA, C. a BÉM, J. Hydraulika. Bratislava: Státní nakladatelství technické literatury (SNTL), 1983.

[4] ANSYS, Inc. ANSYS CFX Tutorials. Release 15. 0. U.S.A., 2013.

[5] ANSYS, Inc. ANSYS CFX - Solver Modeling Guide. Release 15. 0. U.S.A., 2013.

\section{Poděkování}

Tento príspěvek vznikl za podpory grantu SGS16/059/OHK1/1T/11 Výzkum hydraulicky komplikovaného proudění vody na hydrotechnických stavbách.

\section{Autoři}

Ing. Martin Králík, Ph.D.

凶martin.kralik@fsv.cvut.cz

Ing. Tomáš Kašpar

凶tomas.kaspar@fsv.cvut.cz

Ing. Michael Mildner

凶michael.mildner@fsv.cvut.cz

České vysoké učení technické v Praze, Fakulta stavební, Katedra hydrotechniky

Příspěvek prošel lektorským řízením.

\section{FLOW OF THE CURVE OF THE PODKRUŠNOHORSKÝ CANAL}

\section{KRALIK, M.; KASPAR, T.; MILDNER, M.}

Czech Technical University in Prague, Faculty of Civil Engineering, Department of Hydraulic Structures

Keywords: physical modelling - mathematical modelling model similarity - canal - flow of the curve - flow field

This article pursues the hydraulic research of flow of the curve in the Podkrušnohorský canal (PKP). Measurements were conducted on a physical model, which was built by members of the department of Hydraulic Structures in water management laboratory of the Faculty of Civil Engineering, CTU. There was also assembled a 3D mathematical model, on which it is possible to observe velocity, level or the shape of the flow field. The aim of the research is to evaluate traits of flow of the curve using hybrid modelling methods. 